\title{
Climate change and peopling of the Neotropics during the Pleistocene-Holocene transition
}

Guillermo Acosta, Laura E. Beramendi, Galia González, Iran Rivera, Itzel Eudave, Elisa Hernández, Serafin Sánchez, Pedro Morales, Edith Cienfuegos, Francisco Otero

\section{Guillermo Acosta}

acostaochoa@gmail.com

Instituto de Investigaciones Antropológicas, Universidad Nacional Autónoma de México, Ciudad Universitaria, 04510, Mexico.

Laura E. Beramendi

Pedro Morales

Edith Cienfuegos

Francisco Otero

Instituto de Geología, Universidad Nacional Autónoma de México, Ciudad Universitaria, 04510, Mexico.

\section{Galia González}

Instituto de Geofísica, Universidad Nacional Autónoma de México, Ciudad Universitaria, 04510, Mexico.

\section{Iran Rivera}

Itzel Eudave

Elisa Hernández

Serafín Sánchez

Escuela Nacional de Antropología e Historia, Periférico Sur y Zapote s/n. Col. Isidro Fabela, 14030, Mexico.

\begin{abstract}
Santa Marta cave, Chiapas, is a unique archaeological site with high-resolution chronological control and continuous human occupation since $12500 \mathrm{cal} \mathrm{BP}$. In this work we report a correlation between human activity and climate conditions inferred from sedimentological, palynological, archaeozoological and stable isotopic analyses with the aim of assessing the late Pleistocene and early Holocene environmental conditions faced by the first settlers in tropical America. Results suggest that the late Pleistocene and early Holocene periods of abrupt climatic change (ACG), the Younger Dryas and the $8.2 \mathrm{ka}$ event, are recorded in the rock shelter, and coincide with the two main periods of human occupation. The data suggest that these ACG periods were both cold and moist. Human activity had a limited impact at the local or regional level, over a changing environment during the Pleistocene-Holocene transition, though there is some evidence for the introduction of exotic species.
\end{abstract}

Keywords: Abrupt Climatic Change, Anthropocene, Chiapas, Neotropics.

\section{RESUMEN}

La cueva de Santa Marta, Chiapas, es uno de los pocos sitios de los Neotrópicos con alta resolución cronológica que presenta ocupación humana continua desde $12500 \mathrm{cal}$ BP. En este trabajo se correlacionan los datos de actividad humana con las condiciones climáticas inferidas mediante análisis sedimentarios, palinológicos, arqueozoológicos y de isótopos estables en caracoles de río con el fin de evaluar las condiciones ambientales del Pleistoceno final y el Holoceno temprano a las que se enfrentaron los primeros pobladores de las regiones tropicales de América. Los resultados sugieren que los dos principales periodos de cambio climático abrupto (CCA) del Pleistoceno final y el Holoceno temprano (Younger Dryas y evento 8.2 ka) están registrados en el abrigo y coinciden con los dos principales periodos de ocupación humana. Los resultados sugieren que estos periodos CCA fueron fríos y húmedos; mientras que la actividad humana muestra un impacto limitado al nivel local o regional, sobre un entorno cambiante durante la transición Pleistoceno-Holoceno y la probable introducción de especies alóctonas.

Palabras clave: Cambio climático abrupto, Antropoceno, Chiapas, Neotrópicos.
BOL. SOC. GEOL. MEX. 2018

VOL. 70 NO. 1

P. $1-19$

http://dx.doi.org/10.18268/BSGM2018v70nlal 


\section{Introduction: Late Pleistocene peopling of the New World and the onset of the Anthropocene}

The Anthropocene has been defined as the epoch during which human activities impacted the functioning of the Earth System, leaving a footprint in the geological record (Crutzen and Stoermer, 2000; Oldfield et al., 2014). However, there is an ongoing debate on the date of the start of the Anthropocene (Cook et al., 2015; Ruddiman et al., 2015), with suggestions such as the beginning of the Industrial Revolution (AD 1750-1800) or the end of the Second World War and the aboveground nuclear weapon tests. From a long-term perspective, the impact of human beings on the colonized ecosystems since their dispersion from Africa at least 70000 years ago, at different timescales and in diverse aspects, is undeniable.

Thus, it becomes relevant to evaluate the link between climate, paleoecology, and human activity for the last 12000 years (Metcalfe et al., 2000). The aim of this research is to evaluate and distinguish the environmental factors associated with periods of abrupt climate change (ACG) like the Younger Dryas (12800 - $11600 \mathrm{cal} \mathrm{BP})$ and the $8.2 \mathrm{ka}$ event (ca. $8200-8000$ cal BP), and differentiate them from anthropic factors related to the arrival of the first settlers to the Neotropical ecosystems in southern Mexico.

It has been generally accepted that the human impact in the tropical regions of the New World becomes evident towards the mid-Holocene, $c a .7000$ $\mathrm{BP}$, with a significant reduction of arboreal pollen in the paleoecological record associated with a sharp increase of opportunistic plants, pollen of Zea mays, and fire markers (Pope et al., 2001; Neff et al., 2006; Kennett, 2012). This has been considered the onset of extensive slash-burn agriculture. For the societies that predate this period, the human impact has been considered lower and on a local scale as a result of the low population density of the first settlers of the continent (Dillehay, 2000). However, this idea is changing towards a view in which these first settlers had a more active role in the modification of the tropical ecosystems since early periods (Piperno and Pearsall, 1998).

As an example, areas such as the Mexico Basin show evidence of significant population since the Late Pleistocene (González et al., 2006). Evidence of interactions of these first settlers with extinct Pleistocene fauna, such as mammoths (Mammuthus columbi) or American horse (Equus sp.), through hunting has been observed in the Mexico Basin (Aveleyra, 1967) and Chiapas (Acosta, 2012). Furthermore, it has been suggested that these first settlers may have contributed to their extinction (Martin, 1967). The action over the vegetation communities may also have been more intense than traditionally considered. For example, La Yeguada, Panama, Piperno et al. (1991) showed anthropic perturbation dating to $11050 \mathrm{BP}$, such as the massive increase of charcoal and disturbed forest plants, which could be evidence of clearing forest extensions for human activities. This was contemporaneous with the appearance of fluted points (Fishtail) in the Isthmus of Panama (Pearson and Cook, 2002). Unfortunately, studies assessing climate change together with the human footprint in the sedimentary record are scarce.

In this research we aim to highlight also that despite the anthropic footprint of Late Pleistocene and Early Holocene seems to be less evident than in other periods, it should not be ignored from the ecological history of the Neotropics. The longterm records in archaeological sites, such as caves and rock-shelters, may provide information to assess the interaction of these first settlers with a changing environment during the Late Pleistocene and Early Holocene. 


\section{Climatic change and human colonization of the Neotropics: evidence from sites in Mexico and Central America}

\subsection{THE PALEOEGOLOGIGAL REGORD}

The information available for southern Mexico, the Yucatan Peninsula, and other paleoecological records of Central America comes mainly from lakes and cenotes, which, unfortunately, offer a partial and sometimes contradictory record (Metcalfe et al., 2000; Brenner et al., 2002). This record suggests that cold and dry climate conditions prevailed during the Late Pleistocene, with the virtual absence of tropical forest (Leyden et al., 1993; Correa-Metrio et al., 2012; Hodell et al., 2012). Paleoenvironmental reconstructions from southern Mexico to Panama suggest the dominance of pine-oak forests in the highlands mesophyll forest in the wetter regions of the Gulf of Mexico slope; while the drier regions of the Pacific slope and the Yucatan Peninsula appear to have been dominated by deciduous forests, savannas, shrublands, and grasslands (Metcalfe et al., 2000; Piperno, 2012). It is during the Early Holocene that the tropical forest invaded the Peten region in response to warmer and wetter conditions, and shallow lake systems in the north of the Yucatan Peninsula show increases in their water level about $8000 \mathrm{BP}$ as a result of increased precipitation and rising sea levels (Brenner et al., 2002).

\subsection{THE ARCHAEOLOGIGAL RECORD}

One element to emphasize is that the first settlers of the region entered from temperate climates to the tropical ecosystems precisely through Mexico, probably involving the modification of subsistence strategies and improving the knowledge of plants and fauna in environments that were completely new to them. The modification of hunting and gathering strategies implied not only new knowledge about the distribution of resource patches and their seasonality, but also the development of new technologies for the efficient exploitation of tropical environments. Unfortunately, among the archaeological sites reported for the Pleistocene-Holocene transition in the Central American region, only five have reliable chronologies: Los Grifos and Santa Marta, in Chiapas, Mexico (Acosta, 2010, 2011); Los Tapiales and Piedra del Coyote, Guatemala (Gruhn and Bryan, 1977); and Los Vampiros, Panama (Pearson and Cooke, 2002). Among these, only Santa Marta presents a deep sequence of human occupation that allows the evaluation of the environmental conditions and the periods of human occupation during the Late Pleistocene and much of the Holocene (Acosta, 2014).

The technological features of the early settlers in the Neotropics indicate a cultural diversity already present since late Pleistocene, with groups that seem to have focused on the hunting of medium-size fauna, including Pleistocene horses, as seen in Los Grifos, Los Tapiales and Vampiros cave. Other groups with a poorly defined lithic technology did not leave diagnostic projectile points, and were more focused on fresh water snail collection, hunting of minor fauna, and gathering of tropical plants, as recorded in Santa Marta, Chiapas (Acosta et al., 2013; Figure 1).

\section{The Santa Marta rock-shelter as a case study}

As mentioned, the sedimentary history of the Santa Marta rock-shelter offers a good opportunity to evaluate valuable information in an area that has been poorly studied, both in its archaeological and paleoecological record, such as the Central Depression of Chiapas. The first archaeological studies were carried out by MacNeish and Peterson (1962), who were interested in the origin of the domestication of maize. MacNeish and Peterson (1962) identified for the first time Early Holocene occupations. García-Bárcena and Santamaría (1982) continued the research in Santa Marta, 


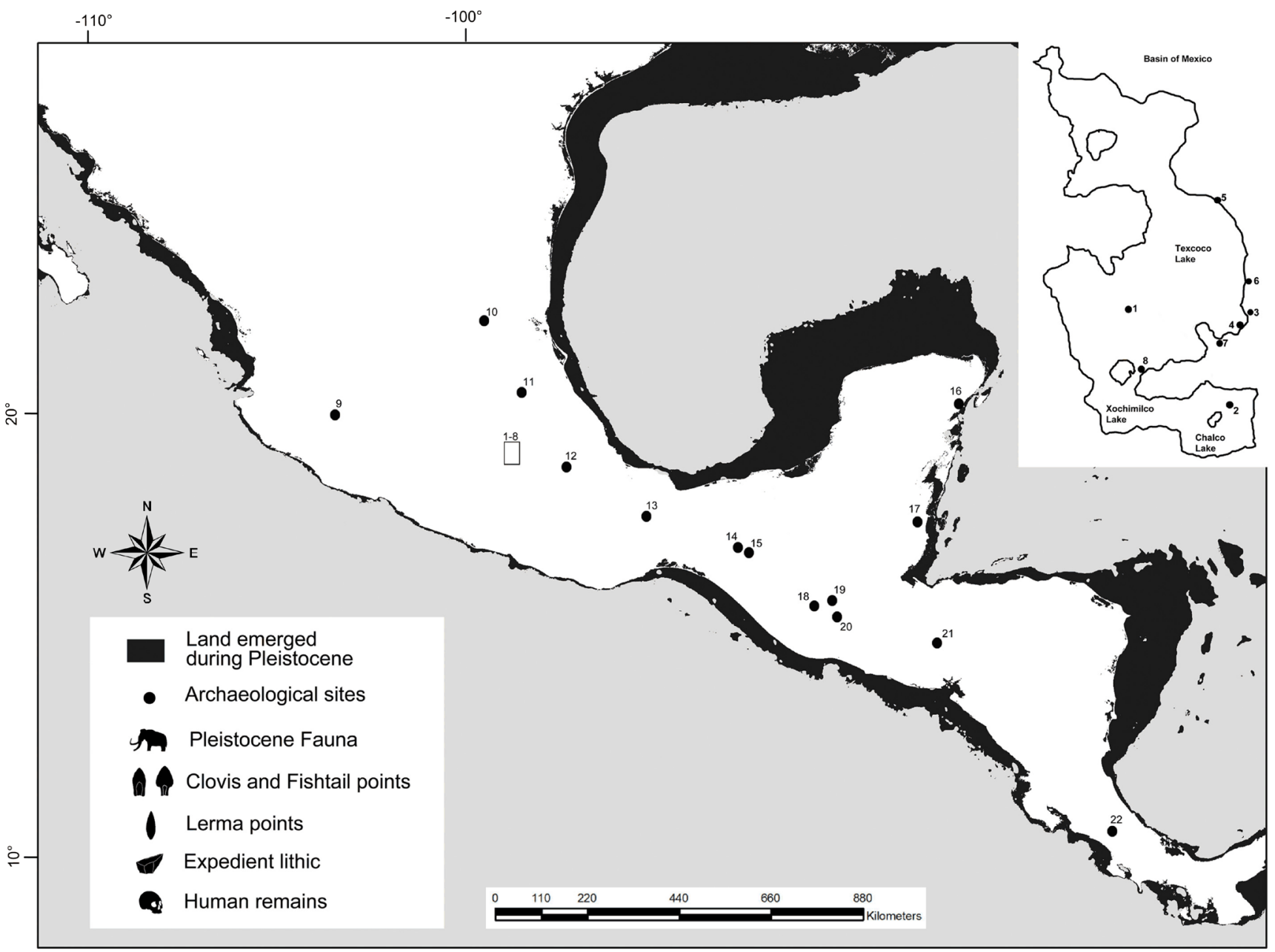

1. Peñon

2. Tlapacoya ha

3. Los Reyes La paz

4. San Vicente Chicoloapan

5. Tepexpan hal

6. Santa Isabel Iztapan y Tocuila hal

7. Chimalhuacan

8. Aztahuacan y Atepehuacan hat

9. Chapala-Zacoalco hil

10. Sierra Gorda

11. Oyapa

12. Valsequillo 1
13. Oaxaca Valley

14. Santa Marta

15. Los Grifos hn a dis

15. Teopisca and Aguacatenango

16. Tulum caves

17. Belize fluted point findings

18. Piedra del Coyote and los tapiales

19. Valle del Quiche and Sacapulas

20. San Rafael

21. La Esperanza

22. Turrialba

Figure 1 Late Pleistocene-Early Holocene archaeological sites of Southern Mexico and Central America (modified from Acosta, 2012, Figure 9.1). 
identifying 11 important phases or occupations that range from the Early Holocene to the colonial period.

In 2004, a regional study was started with the objective of establishing the environmental setting and cultural characteristics of the first settlers of the tropical regions of Mexico. The Santa Marta Cave was excavated again, and Pleistocene occupations were identified for the first time in this site (Acosta, 2008). The earliest dating of Santa Marta confirmed the presence of human groups in the area from at least $12500 \mathrm{cal} \mathrm{BP}$, probably at the beginning of the Younger Dryas. In contrast to the Yucatan Peninsula, for which previous works have suggested the Late Pleistocene as a markedly cold and dry period (Brenner et al., 2002; Escobar et al., 2012; Hodell et al., 2012), studies for Santa Marta suggest a cooler and probably more humid period than present conditions; based on mastofauna (Eudave, 2008), herpetofauna (González, 2015), and pollen remains (Rivera, 2013). Furthermore, macrobotanical remains and pollen indicate a varied vegetation mosaic that included mesophilic, evergreen, and deciduous forest. This mosaic was widely exploited by the first settlers of Chiapas, showing a deep knowledge of Neotropical plants and animals, so one would expect them to have several generations experimenting and developing a cultural system adapted to this changing environment (Acosta, 2008).

In order to evaluate the data available from the Santa Marta rock-shelter for two events of abrupt climate change (Younger Dryas and 8.2 ka event) and their effects on human activity in the cave, we have integrated the data available for the period between 12.5 - $6.5 \mathrm{ka}$ cal BP for the following proxies: sedimentary analyses, pollen, fauna, and oxygen and carbon isotopes in freshwater snail shells (Pachychilus sp.).

\section{Methods}

\subsection{GHRONOLOGIGAL MODEL}

The chronological control of the sequence is based on 13 radiocarbon ages on charcoal samples (Table 1) obtained by Liquid Scintillation Spectrometry and Accelerator Mass Spectrometry. The age-depth model was generated using the online version of OxCal 4.2 (Bronk-Ramsey, 2009) using the Sequence deposition model (Bronk-Rammsey, 2008) and the IntCal 13 calibration curve (Reimer et al., 2013). The model was evaluated in terms of the Agreement Index A calculated by OxCal with an acceptance threshold of $60 \%$ (Bronk-Ramsey,

Table 1. Radiocarbon ages and calibration results for charcoal samples from the Santa Marta rock-shelter.

\begin{tabular}{|c|c|c|c|c|c|}
\hline Sample code & Layer (level) & $\begin{array}{l}\text { Depth } \\
\text { (m) }\end{array}$ & $\begin{array}{c}{ }^{14} \mathrm{C} \text { Age } \\
\mathrm{BP}( \pm 1 \sigma)\end{array}$ & $\begin{array}{l}\text { Modelled age } \\
c a l \text {. BP }(2 \sigma)\end{array}$ & $\begin{array}{c}\text { Median } \\
\text { cal. BP } \\
(2 \sigma)\end{array}$ \\
\hline UNAM-07-28 & III & -1.722 & $5740 \pm 65$ & $6720-6390$ & 6540 \\
\hline UNAM-07-27 & IV & -1.83 & $6800 \pm 97$ & $7790-7430$ & 7600 \\
\hline UNAM-07-26 & $\mathrm{V}$ & -1.925 & $7530 \pm 70$ & $8420-8180$ & 8310 \\
\hline Beta-233473 & VII (level 1) & -2.017 & $7710 \pm 50$ & $8590-8410$ & 8490 \\
\hline UNAM-07-24 & VIII & -2.056 & $7875 \pm 175$ & $8990-8540$ & 8720 \\
\hline Beta-233470 & XI (level 1) & -2.646 & $8740 \pm 50$ & $9910-9550$ & 9720 \\
\hline Beta-233475 & XVI (level 1) & -3.763 & $9800 \pm 50$ & $11320-11170$ & 11240 \\
\hline Beta-357830 & XVI (level 2) & -3.86 & $9950 \pm 40$ & $11360-11220$ & 11270 \\
\hline Beta-357831 & XVI (level 3) & -3.96 & $9850 \pm 40$ & $11360-11230$ & 11280 \\
\hline Beta-357832S & XVI (level 4) & -4.06 & $9990 \pm 40$ & $11590-11240$ & 11330 \\
\hline Beta-233476 & XVI (level 6) & -4.31 & $9950 \pm 60$ & $11620-11260$ & 11390 \\
\hline UNAM-07-22 & XVI (level 7) & -4.351 & $10055 \pm 90$ & $11760-11260$ & 11440 \\
\hline Beta-233470 & XVII (level 2) & -4.557 & $10460 \pm 50$ & $12560-12110$ & 12390 \\
\hline
\end{tabular}


2008). The radiocarbon ages were stratigraphically ordered indicating their position in the sequence. The median calibrated age was obtained every centimeter along the core by interpolation to allow plotting the proxies against age.

\subsection{SEDIMENTOLOGY AND ELEMENTAL ANALYSIS}

The samples used for sedimentology were taken for each stratigraphic unit (layer/stratum) of the sequence obtained from the profile exposed at the end of the excavation unit, collecting approximately $2 \mathrm{~kg}$ of each stratum. Sampling was performed in the profile with better preservation taking samples from the middle of each stratum, starting from the bottom to the top (Figure 2).

The analyses for sedimentology were performed at the Soils and Sediments Laboratory in the Escuela Nacional de Antropología e Historia (ENAH) fol- lowing previously established protocols (Sánchez, 2005). Samples were oven-dried at $75^{\circ} \mathrm{C}$ and sieved through a $2 \mathrm{~mm}$ mesh to separate the fine fraction (clay, silt, and sand). Physical analyses included color determination using the Munsell soil color charts, and texture analyses following the Bouyuocos method modified by Villegas (1979) and the U.S. Department of Agriculture soil textural classification (USDA, 2009). Further, sand fractions were observed under an Olympus SZ-ST microscope to identify morphological features of the particles such as aspect, surficial texture, roundness, and composition, according to Corrales (1977).

Chemical analyses on sediments included $\mathrm{pH}$, organic carbon and phosphorus. The $\mathrm{pH}$ was analyzed following the USDA method (USDA, 2009) with a 1:2.5 soil/water ratio. Soil $\mathrm{pH}$ in natural
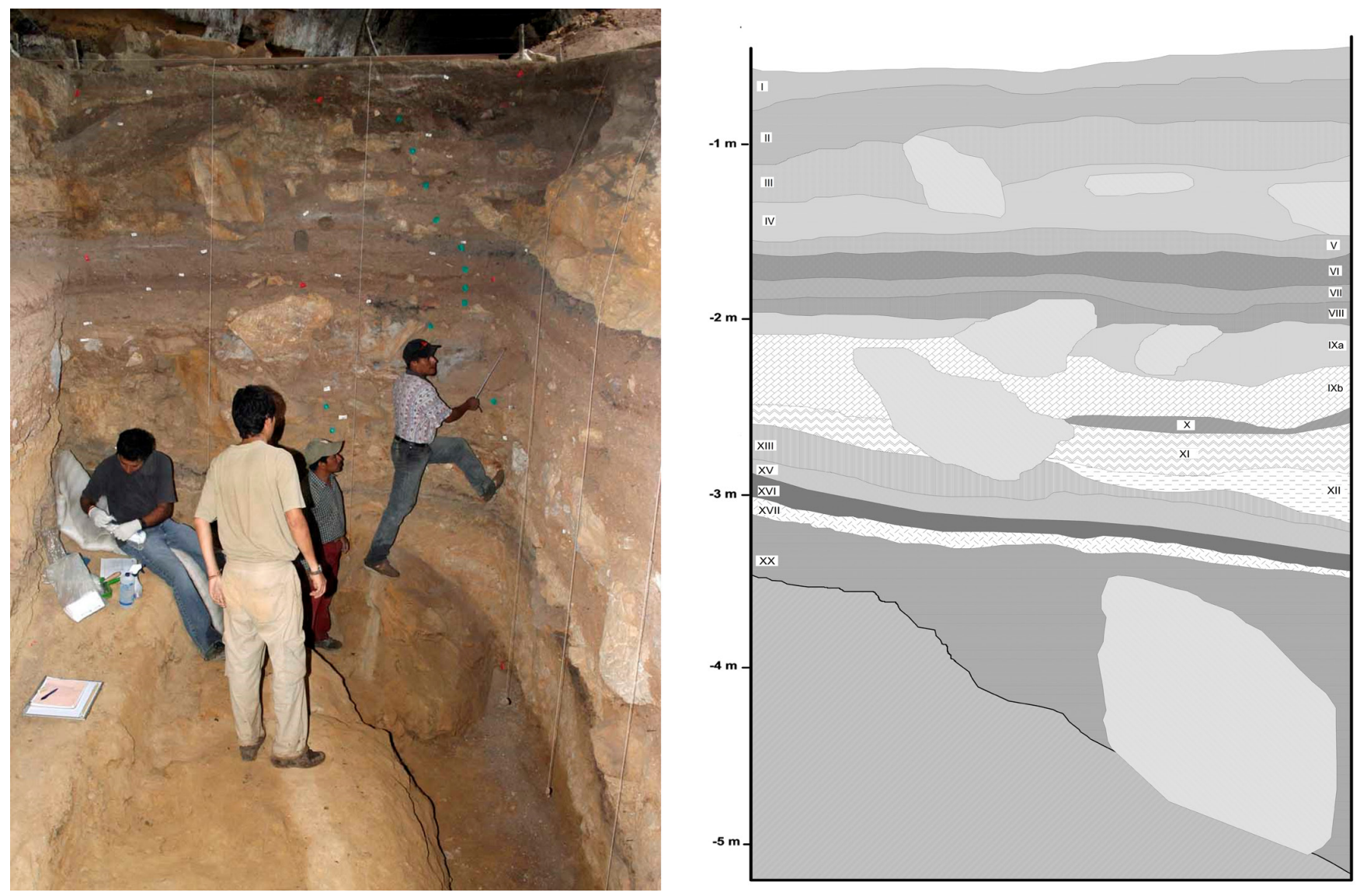

Figure 2 Sedimentary sampling (left) and east profile (right) of the Santa Marta rock-shelter. Green dots on left image represents different strata. 
conditions fluctuates between 4 and 10. An organic soil, with high concentration of humic acids, has lower values $(4-7)$, whereas a soil with high concentration of minerals such as carbonates has values close to 9 . The acidity may increase as a result of roots or microbial action (Sánchez, 2005). The organic matter was analyzed following the method proposed by Walkley and Black (1934). In archaeological contexts the organic matter may have two sources: vegetation growing on the soils covering the site, or transport by some agent, mainly people (Stein, 1990). Phosphorus concentration was established by the semi-quantitative technique described by Eidt (1973). The importance of phosphorus analysis in archaeology is related to the fact that the sources of this element in sediments include bones, stools, urine, meat, and skin, apart from vegetation; thus, it accumulates in areas with human occupation. Moreover, phosphorus has low solubility as phosphates $\left(\mathrm{PO}_{4}^{3-}\right)$ and precipitates as a very stable solid in soils, sediments, or floors; it remains in situ for long time periods, helping in the identification of areas with past human activity.

\subsection{PALEOBOTANIGAL AND ARGHAEOZOOLOGIGAL ANALYSIS}

The palynological study was performed on the layer XVI with the aim of identifying the potential indicators of surrounding flora during the Pleistocene-Holocene transition. Preservation of palynomorphs was poor in the rest of the sequence.

The methodology consisted of the extraction of palynomorphs from discrete samples of the profile as well as from floors with human occupation. The former approach assesses the sedimentary sequence and the flora changes through time, whereas the last approach reflects the spatial distribution of palynomorphs associated with human activities.

The analyses were successfully performed on 48 samples from activity floors within layer XVI: levels 1, 3, and 6, following the modified Erdtman acetolysis method (Nilsson and Praglowski, 1992). Samples used for the archaeozoological analysis correspond to layers XV and XVI, representing the Pleistocene-Holocene transition (Table 2). The analysis included: taphonomic analysis, anatomic and taxonomic identification, sample integrity, fragmentation, surficial marks, and age.

\subsection{GARBON AND OXYGEN ISOTOPES IN Pachychilus sp.}

A characteristic of Santa Marta rock-shelter is the presence of freshwater snails of the genus Pachychilus sp. throughout different portions of the sequence in concentrations associated with fire. The shells are either burned or boiled, indicating that they were consumed as a source of protein (Acosta, 2010).

The Pachychilus sp. samples recovered during the excavation were repeatedly washed with bi-distilled water in an ultrasonic bath to eliminate sediment residues from the interior of the shells, followed by physical cleaning with a Dremel drill and compressed air to remove the carbonates deposits from the shell surface. Finally, samples were rinsed in bi-distilled water in an ultrasonic bath and oven-dried at $50{ }^{\circ} \mathrm{C}$ for 48 hours. Dried samples were milled in a vibratory micro mill with agate mortar and ball. Stable oxygen $\left(\delta^{18} \mathrm{O}\right)$ and

Table 2. List of taxa identified in stratum XV and XVI.

\begin{tabular}{|c|c|c|c|}
\hline Scientific name & Common name & $\begin{array}{c}\text { Number of } \\
\text { samples }\end{array}$ & M.N.I.* \\
\hline Unio sp. & Clam & 1 & 0 \\
\hline Anura & Frog/toad & 10 & 3 \\
\hline Ophidia & Snakes & 47 & 1 \\
\hline Crotalus sp. & Rattlesnake & 32 & 1 \\
\hline Kinosternon acutum & Mud turtle & 40 & 1 \\
\hline Aythya sp. or Anas sp. & Goose or Mallard & 1 & 0 \\
\hline Ortalis vetula & Chachalaca & 2 & 1 \\
\hline Liomys pictus & Pocket mouse & 5 & 2 \\
\hline Dasyprocta punctata & Central American agouti & 8 & 3 \\
\hline Sciurus sp. & Squirrel & 8 & 2 \\
\hline Dasypus novemcinctus & Armadillo & 69 & 0 \\
\hline Silvylagus floridanus & Rabbit & 23 & 2 \\
\hline Lepus sp. & Hare & 4 & 1 \\
\hline Bassariscus sumichrasti & Cacomistle & 2 & 1 \\
\hline Canis sp. & Canid & 1 & 0 \\
\hline Urocyon cinereoargentus & Gray fox & 2 & 1 \\
\hline Artiodactyla & Ungulate & 29 & 1 \\
\hline Dicotyles tajacu & Collared peccary & 7 & 2 \\
\hline Cervidae & Deer & 120 & 4 \\
\hline Odocoileus virginianus & White tailed deer & 79 & 4 \\
\hline Mazama americana & Brocket deer & 13 & 1 \\
\hline TOTAL & & 510 & 33 \\
\hline
\end{tabular}


carbon $\left(\delta^{13} \mathrm{C}\right)$ isotope analyses were performed in the Stable Isotopes Laboratory at the Instituto de Geología, UNAM. Samples were acidified with $\mathrm{H}_{3} \mathrm{PO}_{4}$ at ambient temperature in a GC PAL autosampler coupled, via a Gas Bench II interface, to a Finnigan MAT253 stable isotopes spectrometer. Results for both isotopes are reported relative to the Vienna Pee Dee belemnite standard (VPDB) with a precision of $0.2 \%$.

\section{Results: the proxies}

\subsection{GHRONOLOGY}

Results for the calibration of the age-depth model (Figure 3) are in good agreement with the data, having an overall A index of $83 \%$, and uncertainties $(1 \sigma)$ for the tie points ranging between 50 and 140 years. A relevant feature of the age-depth model is the changing sedimentation rate, presumably as a result of the human activity in the shelter. The higher accumulation rate is between 3.76 and $4.35 \mathrm{~m}$, corresponding to the $11200-11500 \mathrm{cal}$ $\mathrm{BP}$ period, with a mean value of $0.3 \mathrm{~cm} / \mathrm{yr}$, coincident with the layers with more intense human activity as revealed by the other proxies discussed in the following sections.

It is important to mention that despite the lack of datable material between 2.2 and $2.6 \mathrm{~m}$, and between 2.7 and $3.7 \mathrm{~m}$, we are assuming that the sediment accumulation continued with no hiatuses.

\subsection{SEDIMENTS}

Sediments are mainly formed by material resulting from weathering of the rock shelter, such as lithic fragments, quartz, pyroclasts, and other components of eolic origin. The strata also contain elements of anthropic origin like organic matter and $\mathrm{PO}_{4}^{3-}$ derived from the decomposition of vegetal and animal tissues. Values for both of these parameters are extremely high, up to $14 \%$ for OM and up to $5 \%$ for $\mathrm{PO}_{4}^{3-}$, indicating intense human activity on most of the surfaces of the identified strata. The layers with evidence of increased

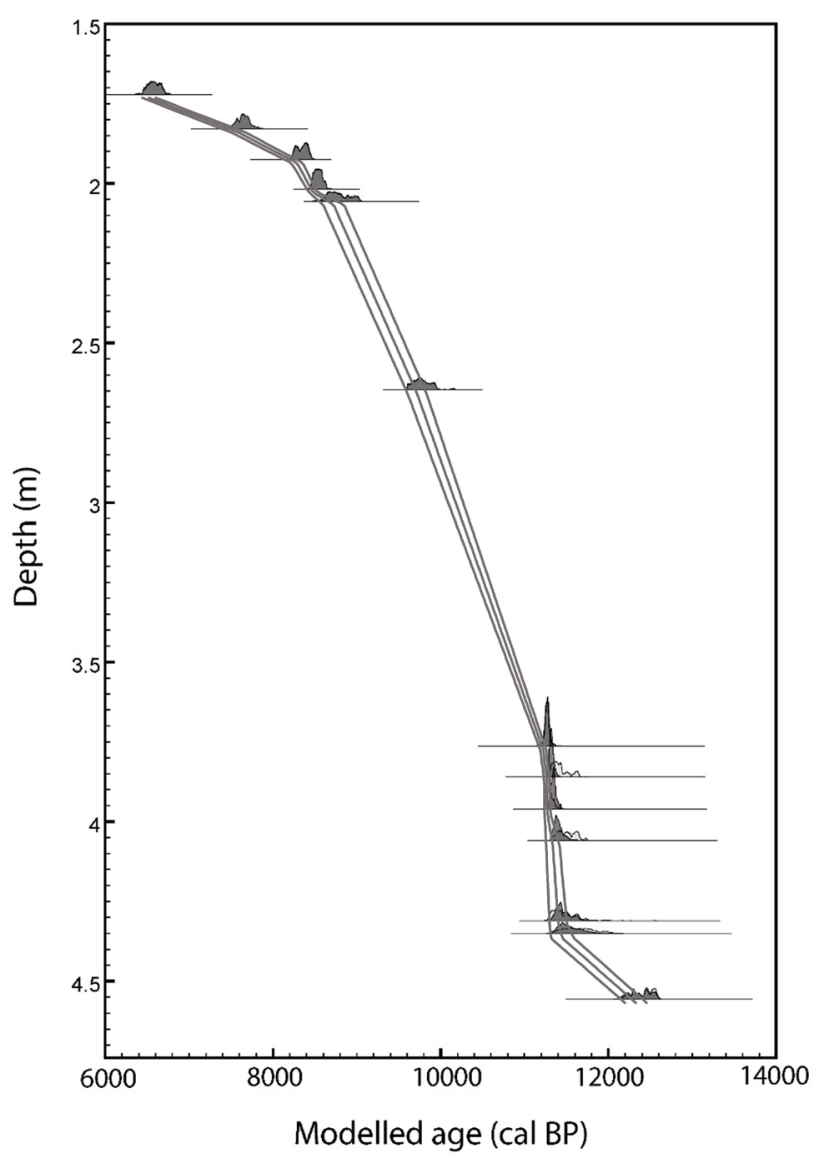

Figure 3 Age-Depth model for Santa Marta. Areas correspond to the probability density distribution for the calibrated ages and lines correspond to the median values with the $\pm 1 \sigma$ envelope, obtained by interpolation every centimeter.

human activity are V, VII, and XVI. Layer XVI corresponds to an important period in the history of the shelter, the Younger Dryas, considering the abundance of human activity indicators (Acosta, 2010). The presence of organic matter is evident by the brown color of the sediments. The presence of salts is represented by the $10 \mathrm{YR} 5 / 2$ greyish brown to $10 \mathrm{YR} 3 / 2$ very dark brown. Further, the $\mathrm{pH}$ of this layer is basic (7.6) as a result of the salts derived from fires for food preparation. The organic matter is very abundant $(10.6 \%)$, although not as abundant as in the previous two layers, and the phosphate concentration is also high. These three parameters, related to intense human activities, are in agreement with the abundance of archaeological materials recovered from this layer (Acosta, 2008). 
Regarding the textural analysis, clay content is low $(2 \%)$ whereas the most abundant fraction is sand $(69 \%)$ followed by silt $(29 \%)$. The textural class is "sandy loam." Approximately $50 \%$ of the sand fraction particles observed under the microscope have a frosted surface with a nearly spherical grain morphology and small impacts on the surface, characteristic of eolic sediments. The other $50 \%$ of sand particles correspond mainly to minerals coming from the rock-shelter and a higher amount of pyroclasts, probably also with eolic origin. This is more evident in layer XVII, which marks the start of the human occupation in the rock-shelter and is the stratum with higher sand content, decreasing during periods of higher occupation intensity of the shelter.

\subsection{POLLEN}

The palynological analysis yielded positive data only for layer XVI, as a result of poor preservation of this material throughout the sequence. It was possible to identify nine families and 25 mor- fotypes characteristic of different habitats. The pollinic sum is 6684 palynomorphs, distributed on the three floors (levels 6, 3, and 1) of layer XVI (Figure 4).

On level 6 ( $c a .11390 \mathrm{cal} \mathrm{BP})$ no pollen grains were recovered. However, multicellular spores are preserved, although not very abundant.

On level 3 (ca. $11280 \mathrm{cal} \mathrm{BP}$ ), 686 palynomorphs were counted, of which $61 \%$ are pollen grains and $39 \%$ are spores. Of the identified arboreal families, the more represented are Betulaceae (Carpinus sp., Alnus sp.), Pinaceae (Pinus sp.), Fagaceae (Quercus sp.), Myrtaceae (Psidium sp.), and Sterculiaceae (Theobroma sp.). The 38\% of the recovered palynomorphs on this level are multicellular spores.

On level 1 ( $c a .11240 \mathrm{cal} \mathrm{BP})$ there is a considerable increase of pollen, recovering 5998 grains representing nine families and 25 morfotypes. The degree of preservation of this material was very good, with $38 \%$ of the total counts correspond to Psidium sp., and 30\% corresponds to Alnus sp. Others identified, but less represented, are Arecaceae, Apocynaceae, Sterculiaceae, and other genera
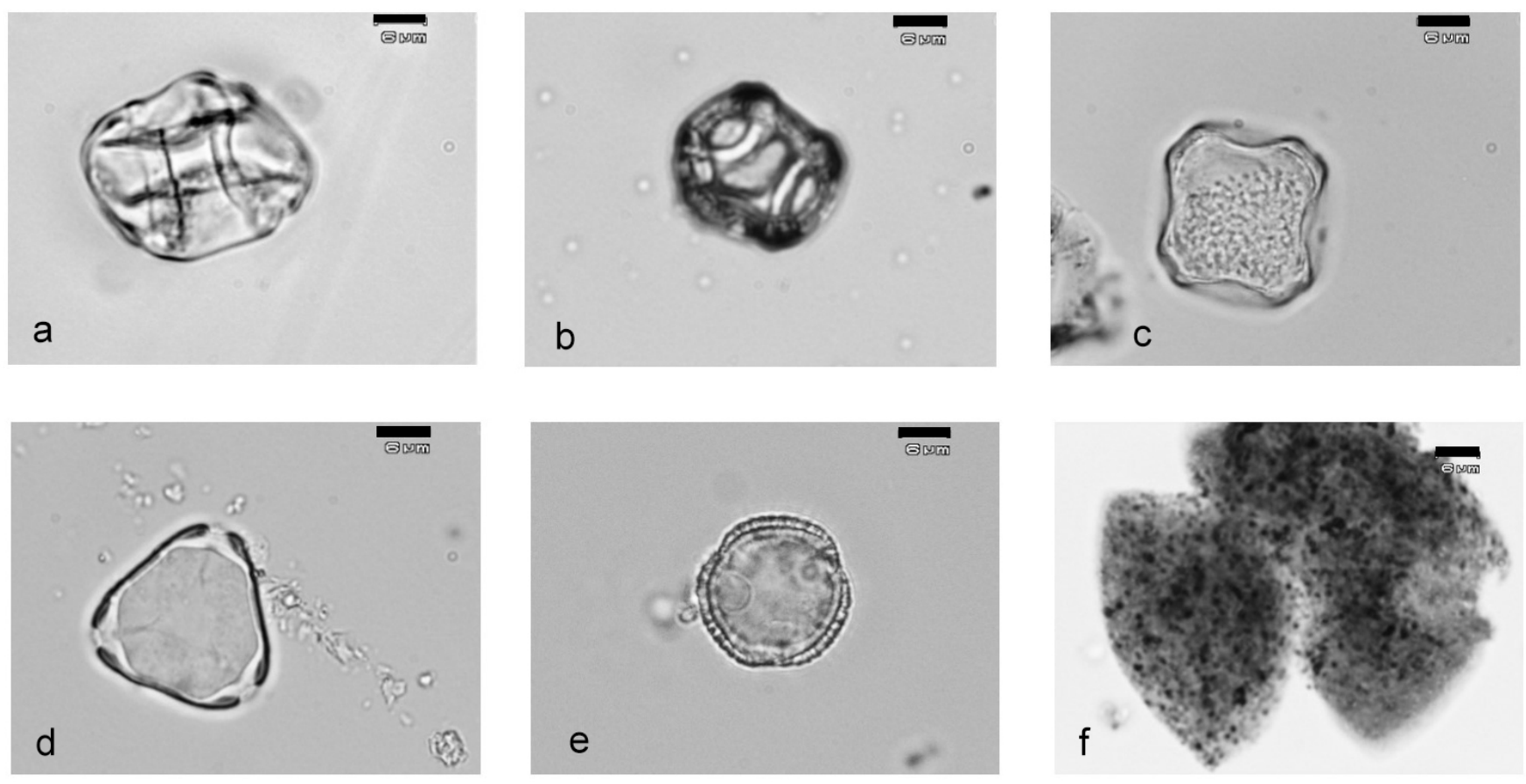

Figure 4 Palinomorphs of the 8.2 ka event (a-c) and Younger Dryas (d-f). a. Echites sp. b. Tabernaemontana sp. c. Psidium sp. d. Pimenta dioica e. Theobroma cacao f. Turnera difussa. 
of Myrtaceae. These results suggest that, in general, the archaeological materials associated with human activities are well preserved in the Santa Marta sediments. These palynomorphs represent a sequence of changes in the environment, reflected by the presence or absence of some genera in the three analyzed floors.

On level 6, the presence of fungi spores are potential indicators of humidity and, at the same time, the absence of pollen particles suggests particular environmental conditions that resulted in the non-preservation of the last ones in the sediments. On level 3, there are arboreal palynomorphs from morfotypes such as Quercus sp. and Pinus sp., indicating a Pinus-Quercus forest, which corresponds to the present vegetation in the temperate area of Chiapas, with annual precipitation less than $1200 \mathrm{~mm}$ (Miranda, 1952). On the other hand, the presence of pollen grains with Psidium affinity is also registered. There are some species of this genus that need between 1000 and $350 \mathrm{~mm}$ of annual rainfall and temperatures ranging from 15 to $34^{\circ} \mathrm{C}$.

On the upper level of this layer, corresponding to floor 1 , the variety of families and genera increases considerably. The identified taxa on level 3 are still present; however, there are new ones related to a tropical forest. The potential indicators of an increase in precipitation and temperature include families such as Myrtaceae (aff. Psidium sp. and Pimenta dioica) and Sterculiaceae (Theobroma sp.). The conditions for a successful development of these tropical taxa are between 1000 and $3500 \mathrm{~mm}$ of annual precipitation and temperatures between 20 and $30^{\circ} \mathrm{C}$.

\subsection{ARGHAEOZOOLOGICAL REMAINS}

The archaeozoological analyses were performed on 649 bone and nine shell samples. It was possible to identify 29 taxa, with $76 \%$ corresponding to mammals, $19 \%$ to reptiles, and the rest to avifauna, amphibians, gastropods, and bivalves. The Pachychilus sp. was not included in this analysis because they were so abundant that they were not individually registered during the excavation; the only registered information was the weight of each level before the carbon isotopes analyses (Martínez, 2013).

Most of the materials show signs of thermal processing, butchering marks, and dismembering, all associated with the consumption as food. The identified taxa during the first faunal study (Eudave, 2008) included taxa related to tropical environments, either open or closed, with abundant freshwater snail shells (Pachychilus sp.) and mud turtles (Kinosternon sp.), suggesting more humid conditions than at present. A more detailed study of the herpetofauna (González, 2015) suggested more humid conditions during the PleistoceneHolocene transition than at present, with the presence of medium and high tropical forests. The presence of Kinosternon acutum in Santa Marta indicates a change in the distribution of this species (currently limited to 0-300 $\mathrm{m}$ above sea level) as a result of the environmental changes towards the end of the Pleistocene and beginning of the Holocene. Furthermore, the carbon and oxygen stable isotope values on a Mazama americana bone sample $\left(\delta^{13} \mathrm{C}\right.$ : $-9.49 \%$, $\left.\delta^{18} \mathrm{O}:-1.65 \%\right)$, reported by Pérez-Crespo et al. (2012), reinforce the presence of a closed vegetation environment around Santa Marta.

\subsection{OXYGEN AND GARBON ISOTOPIC COMPOSITION OF Pachychilus sp.}

The $\delta^{18} \mathrm{O}$ values range between -5.55 and $-0.82 \%$, and the $\delta^{13} \mathrm{C}$ range between -11.73 and $-6.70 \%$. There is a significant correlation between the variations of both isotopes $(\mathrm{r}=0.792, \mathrm{p}<0.001)$. It is possible to distinguish two groups: (a) more negative values for both isotopes corresponding to the $8.3-6.49 \mathrm{ka}$ cal BP period (except the sample associated with the 8.2 ka event, which has significantly higher $\delta^{18} \mathrm{O}$ values), and (b) less negative values for samples corresponding to the Pleistocene-Holocene transition (Figure 5). The significant correlation between the isotopes suggests that both were controlled by common mechanisms, 


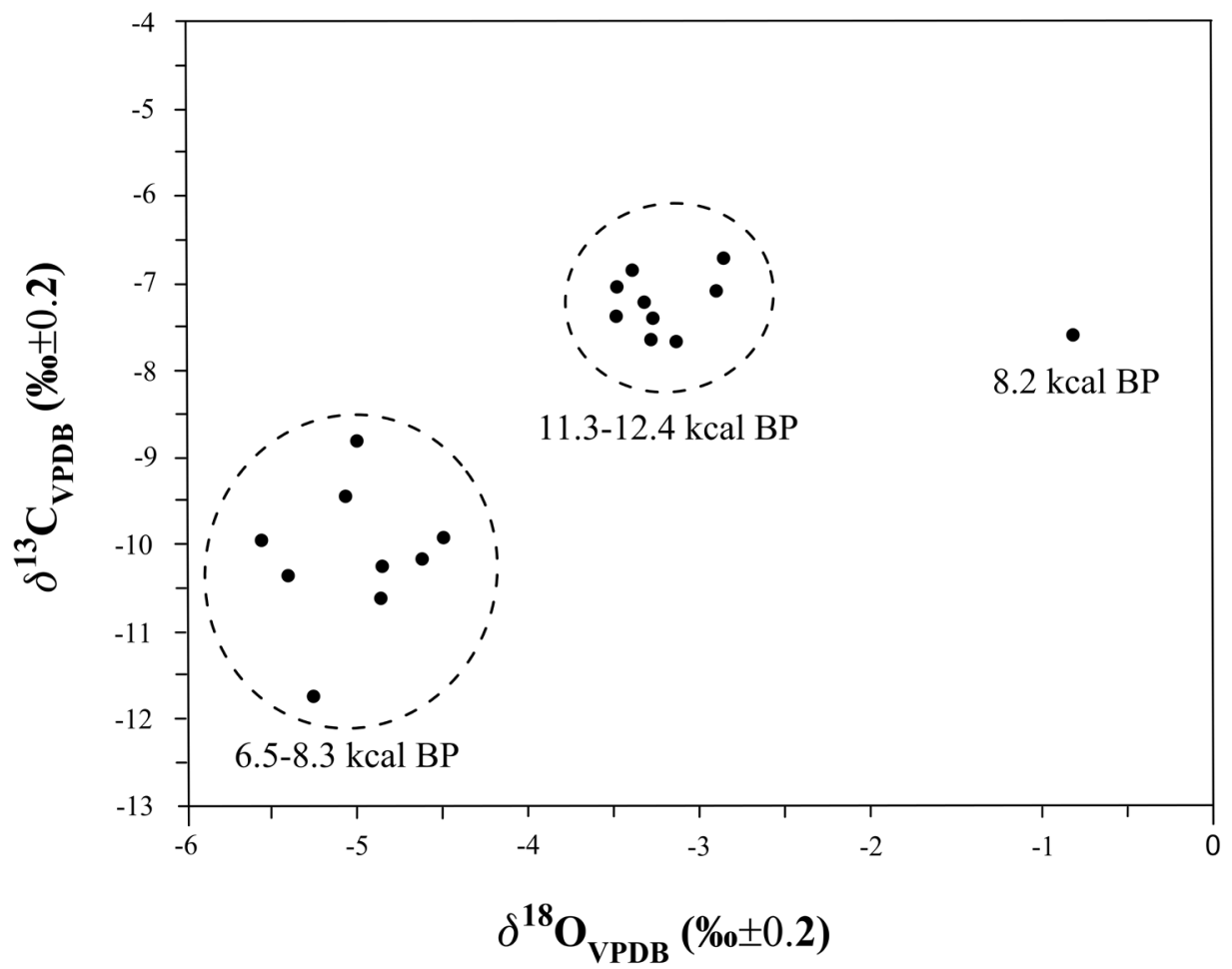

Figure $5 \delta^{13} \mathrm{C}$ versus $\delta^{18} \mathrm{O}$ values in Pachychilus snails of Santa Marta rock-shelter.

and that the carbon incorporated into the shells derives mainly from dissolved inorganic carbon in the river water.

\section{Pleistocene-Holocene climate change: a comparison of the proxies}

\subsection{SEDIMENTOLOGY AND HUMAN AGTIVITY}

Caves and rock-shelters are complex deposits where sedimentary processes do not follow the principles of classical sedimentary records as lacustrine sediments; however, their importance as paleoenvironmental records has increased recently. The main challenge in the study of these deposits is to distinguish between natural agents and those of anthropic origin (Farrand, 2001). Unfortunately, the paleoenvironmental studies for this type of site are very scarce, and mainly on speleothems of humid caves (Sasowsky and Mylroie, 2012). Santa Marta is a good example that caves and rock shelters are natural traps that allow the preservation of wide sedimentary sequences of eolic and anthropic origin that could fill the little represented periods in lacustrine sequences. In this sense, the sand fraction seems to have a direct correlation with periods of increased erosion, and its frosted appearance suggests wind deposition, while its proportion decreases towards the end of the Pleistocene. This coincides with other proxies (pollen and fauna) that indicate an increase of humidity for this period. At the beginning of the 8.2 ka event, there is a slight decrease in the proportion of sands, and it increases again at the end of this period. In the case of organic matter, although one would expect a direct relationship with human activities, this does not appear to be the case, the abundance of organic matter seems to be related to low humidity conditions that allowed its preservation. In contrast, phosphates seem to have a greater correlation with periods of human activity, as their concentration increases along with the human occupation floors, so they can be interpret- 
ed mainly as a result of human waste; however, their variation is less sensitive throughout the sequence (Figure 6).

The total number of lithic artifacts (mainly flint and shale) for each stratum and level is probably the best indication of the intensity of human occupation. The most intense occupation of the rock shelter occurs at the end of the Pleistocene, then decreases drastically during the Early Holocene, and later experiences pulses of sporadic occupation between 9000 - 8300 cal BP, with a second intense occupation (although smaller than in the Late Pleistocene) that coincides with the $8.2 \mathrm{ka}$ event. The coincidence of the two most intense occupations of the site with the main abrupt climate change periods, such as Younger Dryas and $8.2 \mathrm{ka}$ event, can be explained if these events are considered to coincide with wetter periods in the sequence of the site. In this case, the rock shelter had to be constituted as an important refuge in rainy season, with a significant source of protein from the permanent flow of the nearby river.

\subsection{FLORA AND FAUNA RESOURGES}

The fauna recovered in the cave is relatively sparse, except at the levels of the Pleistocene-Holocene transition, with typical organisms of the Neotropics. The main source of protein during the main occupation periods is represented by freshwater snails of Pachychilus sp. and its distribution coincides with humid periods. The herpetofauna remains (González, 2015) suggests vegetation with greater affinity to the medium and high tropical forest, while the presence of Kinosternon acutum, a turtle whose distribution is currently located north of the state, restricted to areas with a more humid climate and vegetation of high and medium forest, indicate a more humid and forested climate.

On the other hand, the archaeobotanical study allowed us to recognize seeds of deciduous forest taxa such as Celtis sp. (hackberry) and Byrsonima crassifolia (nance), but also fruits of medium and high forest such as Bumelia laetvirens (cajpoquí), and different opportunistic plants of human utility like Physalis sp. (green tomato).

Palynological data show that during the Pleistocene-Holocene transition, pine and elder communities were probably at lower altitudes than at present, and are the best represented morphotypes for this period. Although the palynological sampling was performed horizontally, with the intention of recovering pollen material associated with the different areas of activity of a base camp, the

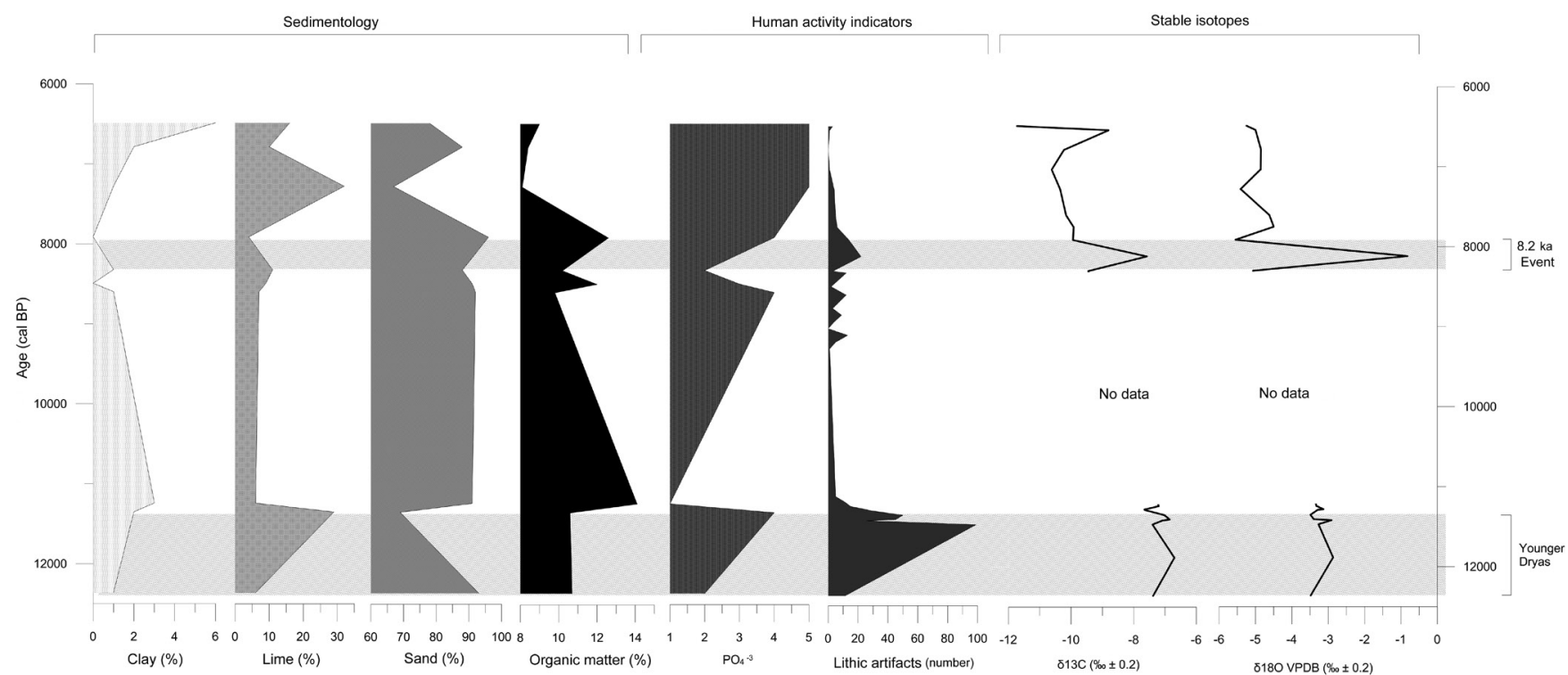

Figure 6 Proxies plotted against age. The abrupt climate change events are shown as gray lines. $\mathrm{PO}_{4}^{-3}$ in semi-quantitative values. 
initial Holocene floors retained pollen showing a marked change tending to warmer climates, such as the tropical rainforest and deciduous forest. The increase in taxa of these ecosystems brought a great amount of morphotypes with alimentary, medicinal, and/or ritual use. The best represented family was Myrtaceae, with abundant pollen grains that have affinity with Psidium, in addition to Pimenta dioica, which is used within the Zoque community of the region near Santa Marta as a ritual type plant and as condiment. The presence of palms of different morphotypes is an environmental marker of undergrowth, which shows that there were resources available for the elaboration of basketry, and the palm fruits are often used as food. Other edible fruits may have been Annonaceae (anonas), which have a wide variety of genera in the Mexican southeast and are consumed as food or medicinal use. The presence of the genus Theobroma is remarkable because it needs specific environmental conditions for its growth and reproduction. It is one of the most representative examples of the Chiapas tropical forest. The nutritional, ritual, and medicinal uses of Theobroma cacao are well-known. The presence of pollen and starches of Zea mays suggests either that the Huehuetenango teosinte (Zea mays ssp. Huehuetenangensis) was located to the west of its present distribution or that it represents a plant introduced by humans, as no native teosintes are currently reported in the Central Depression of Chiapas.

\subsection{ISOTOPES ON Pachychilus sp. AS TEMPERATURE AND HUMIDITY PROXIES}

The Pachychilus genus is a snail with an oblong-conic solid shell, whose habitat is characterized by surficial waters with less than $40 \mathrm{~cm}$ depth, well oxygenated and moving. They can be found in shaded areas under leaves and branches where they feed. The population density is high, with up to 1200 specimens per square meter, so it can resist substantial harvest pressure (Emery, 1986; Lam et al., 2012). Nowadays there is a temporal stream bank near Santa Marta, which may have had a constant flow during the Late Pleistocene, according to pa- leoenvironmental studies (Acosta, 2008; Rivera, 2013) and the results presented here. This stream could have been the collection site of the Pachychilus shells recovered in the pre-ceramic occupations in Santa Marta. The absence of the snails in the sedimentary record for the period between 11 and $8.5 \mathrm{ka}$ cal BP, despite coincident with a period of decreased human activities in the site, appears to be associated with a decrease in precipitation and the temporal disappearance of the availability of this resource.

Stable isotopes in freshwater snail shells have been used as paleoenvironmental proxies. The $\delta^{18} \mathrm{O}$ has been reported as an indicator of the precipitation/evaporation ratio in closed lakes (Brenner et al., 2002), and of temperature and precipitation in open systems including rivers (Leng and Lewis, 2016). On the other hand, the $\delta^{13} \mathrm{C}$ is mainly controlled by the water-atmosphere $\mathrm{CO}_{2}$ exchange and the concentration of dissolved inorganic carbon, and to a lesser extent by the metabolic processes of the snail (Jones et al., 2002); thus the $\delta^{13} \mathrm{C}$ in river snails can be considered an indicator of precipitation. However, the diversity of carbon sources for the snail complicates the interpretation of the results.

The values of $\delta^{18} \mathrm{O}$ in the shells of the earlier occupations of the Santa Marta rock-shelter range between -3.49 and $-2.87 \%$ (average $-3.24 \%$ ) during the Pleistocene-Holocene transition period. Towards $8.3 \mathrm{ka}$ cal BP, after a period without snails in the sequence, samples are again recorded with $\delta^{18} \mathrm{O}$ values significantly more negative, varying between -4.5 and $-5.5 \%$ (mean $-5.01 \%$ ). An exception to this is the sample with an age of about $8.2 \mathrm{ka}$ cal BP, which has enriched values in the two heavy isotopes $\left(\delta^{18} \mathrm{O}=-0.82 \%\right.$ and $\delta^{13} \mathrm{C}$ $=-7.58 \%$ ).

Although this is the first work reporting values of isotopic composition of Pachychilus snails, it seems that it is possible to associate these changes to variations in temperature and humidity, and use them as environmental proxies. According to the other proxies studied in this work, the Pleistocene-Holocene transition period, as well as the 8.2 ka event, 
were characterized as periods of higher humidity, and based on $\delta^{18} \mathrm{O}$ values in Pachychilus shells, related to low temperatures (Leng and Lewis, 2016). During colder periods, precipitation in tropical regions becomes enriched in the heavy isotope (i.e., higher values of $\delta^{18} \mathrm{O}$ ), so the isotopic composition of water in rivers, and thus the Pachychilus species inhabiting there, would also become more positive. During the Early Holocene, the absence of Pachychilus, coinciding with a decrease in human activity in the site, appears to be associated with a dry period.

Approaching $8.5 \mathrm{ka}$ cal $\mathrm{BP}$ there is again the presence of processed snails in the archaeological record, suggesting conditions of humidity favorable for the Pachychilus snails. The isotopic compositions of the shells have more negative values (except for 8.2 ka event) suggesting warmer temperatures than during the Pleistocene-Holocene transition.

\section{Concluding remarks}

Caves and rock shelters such as Santa Marta, with a thick sedimentary sequence, are an excellent opportunity to evaluate the climatic history of the last 13000 years in the Neotropics, while their permanent use by human groups since the Late Pleistocene allow us to study early human impact on these ecosystems. The main challenge of this type of sequences is to distinguish between climatic and anthropic signals. The proportion of sand in the sediments and the evidence of abrasion on the surface of sand grains are indicators of environmental conditions and sedimentary process. Other indicators such as increased organic matter also appear to be indicative of drier periods. In contrast, freshwater snails (Pachychilus sp.) appear to be a good climatic marker at a local level, as they reproduce in periods of higher humidity, when there was a permanent flow of water near the cave. Moreover, their isotopic values are independent of human influence and they are a good proxy for humidity and temperature. The remarkable isotopic variations in the shells and their relationship with other environmental indicators suggest that the Pachychilus snails appear to be a good climatic indicator, but it is necessary to expand their study, since when growing in an open system, the oxygen isotopes in the snails present a different systematics from those found in lakes.

In the case of faunal remains, only the herpetofauna seems to have any usefulness to evaluate the moisture conditions and vegetation type, as has been demonstrated in other caves in southern Mexico (Cruz et al., 2016). However, its usefulness is limited to identifying diagnostic species such as Kinosternon acutum, which indicates tropical forest vegetation and wetter conditions than present. The faunal isotopic studies also allow us to determine the local vegetation, as in the case of the Mazama americana, that suggests a diet linked to a closed vegetation environment. Pollen is more complicated to evaluate, mainly because its low preservation along the sequence does not allow a complete palynological record. In Santa Marta, the excellent preservation of pollen on the human occupation floors indicates that the specific conditions of compaction and $\mathrm{pH}$, among others, allow its differential preservation, but specific environmental conditions such as those observed in level 6 (at the beginning of Younger Dryas) also affect its presence. Although we recognize that it is more difficult to separate the human signal from that of the environment in the study of pollen, the analysis of arboreal and anemophilic pollen seems to be of some utility to evaluate local vegetation and its diachronic change.

The overall evaluation of the proxies used in this study allows us to recognize the environmental signals that suggest that the Younger Dryas and 8.2 ka events were predominantly humid and cold in the Central Depression of Chiapas. The decrease of the mean annual temperature for these events coincides with the results of the study of ice cores in Greenland (Alley, 2000; Alley and Ágústsdóttir, 2005). Prevailing dry conditions have been suggested for this event, both in the Northern Hemisphere (Alley and Ágústsdóttir, 2005) and in the Neotropics, based on sediments of the Cariaco Basin, Venezuela (Haug et al., 2001), and speleo- 
thems of Venado Cave in Costa Rica (Lachniet et al., 2004). However, a study of oxygen isotopes in terrestrial snails in New Mexico registered the Younger Dryas as a cold period with higher relative humidity (Balakrishnan et al., 2005). This is in agreement with our study and the records of the mountains of central Mexico, where there have been significant advances in glaciers, especially those associated with the $8.2 \mathrm{ka}$ event, suggesting that it is a cold and humid event for Mexico (Vázquez-Selem and Heine, 2004).

The sedimentary and archaeological record of the Santa Marta rock-shelter provides important information about the human presence in the tropical regions of southeastern Mexico and its impact on the environment. In this sense, we must clarify that we do not consider the Anthropocene as a unique event with a specific starting date, but as a long-term process that begins with the migration of the first modern humans outside Africa, at least 70000 years ago, and the anthropogenic impact must be assessed in different scales and forms, according to the different chronological and cultural periods. Thus, it is likely that with their entry into new continents, Pleistocene humans could directly or indirectly cause the extinction of native species, as has also been proposed with the entry of the first settlers to the New World (Martin, 1967). As mentioned above, the first human groups entered the Neotropics in Mexican territory, and hunting of extinct fauna (Pleistocene horse) has been reported in sites of the Pleistocene-Holocene transition, such as Los Grifos rock-shelter (Acosta, 2010, 2012), so the interaction of these first settlers with extinct fauna is unquestionable. However, it is not possible to determine whether their extinction is directly associated with systematic hunting.

Santa Marta, despite being located less than $1 \mathrm{~km}$ away from Los Grifos, has no evidence of hunting for Pleistocene fauna, yet human action on tropical ecosystems is clearly seen in plant remains. These indicate that the first settlers of the area not only knew and efficiently exploited the different tropical ecosystems, but could influence the distribution of some species, with early spreading of plants such as Zea mays (teosinte) and Theobroma cacao (cacao) between 12 and $9.8 \mathrm{ka} \mathrm{BP}$.

On the other hand, archaeological evidence indicates that during the Early Holocene the inhabitants of these tropical regions did not produce such a significant impact on the environment as recorded from the Middle Holocene. However, the human record in Santa Marta is scarce between 9.8 and $8.5 \mathrm{ka} \mathrm{BP}$, probably due to decreased precipitation that dried the nearby stream and forced human groups to migrate to areas with greater availability of resources and open sky locations. During the 8.2 ka event, paleoethnobotanical evidence indicates the presence of desiccated tubers of yumi (Dioscorea cymosula), Sapotacae pollen, and starch granules of sweet potato (Ipomoea batatas), beans (Phaseolus sp.), and yam (Dioscorea trifida), so a low-scale horticulture is not discarded.

Between 7.0-5.0 ka BP, paleoecological records in the lowlands of Mesoamerica show the first signs of slash-burn agriculture, suggesting a significant human impact on tropical lowland ecosystems (Brenner et al., 2002; Kennett, 2012). Unfortunately, the cultural remains in the Santa Marta sedimentary registry are scarce between 8.0 and $6.0 \mathrm{ka} \mathrm{BP}$, which suggests that there was less human occupation in the area, or that human groups began to abandon caves and rock-shelters for more-permanent settlements in open areas. In this sense, it should not be ruled out that the inhabitants of the tropical lowlands could begin to develop permanent or semi-permanent settlements with higher demographic density as those observed in the basin of Mexico during the same period (Niederberger, 1979; McClung and Acosta, 2015). However, these sites have yet to be investigated in the lowlands of Mesoamerica since they have not been located. For this reason, the study of these early settlers of the Neotropics should be continued and extended if we want to know how these early settlers carried out the first domestications in Mesoamerica and how they gave rise to the first permanent villages of the New World. 


\section{Acknowledgements}

This study was possible thanks to the support of funds granted by the Consejo Nacional de Ciencia y Tecnología (CONACyT I0017) and the Programa de Proyectos de Investigación e Innovación Tecnológica (PAPIIT IG400217). We are grateful for the support of the students Osvaldo Orihuela, Yesica Martínez, and Diana Blancas in the preparation and processing of the Pachychilus samples.

\section{References}

Acosta, G., 2008, La cueva de Santa Marta y los cazadores-recolectores del Pleistoceno final-Holoceno temprano en las regiones tropicales de México: México, Universidad Nacional Autónoma de México, doctoral thesis in Anthropology, $390 \mathrm{p}$.

Acosta, G., 2010, Late-Pleistocene/EarlyHolocene Tropical Foragers of Chiapas, Mexico: Recent Studies: Current Research in the Pleistocene, 27, 3-5.

Acosta, G., 2011 , El poblamiento de las regiones tropicales de México hace 12500 años: Anales de Antropología, 45-I, 227-235.

Acosta, G., 2012, Ice Age Hunter-Gatherers and Colonization of Mesoamerica, in Nichols, D.L., Pool, C., (eds.), Oxford Handbook of Mesoamerican Archaeology: New York, Oxford University Press, 129-140.

Acosta, G., 2014, Nuevos estudios sobre las sociedades precerámicas de Chiapas, in Corona-Martínez, E., Arroyo Cabrales, J., (eds.), Perspectivas de los estudios de prehistoria en México: Un homenaje a la trayectoria del ingeniero Joaquín GarcíaBarcena: México, Instituto Nacional de Antropología e Historia, 143-167.

Acosta, G., Martínez, P., Rivera, I., 2013, Metodología para el estudio del procesamiento de plantas en sociedades cazadoras-recolectoras: un estudio de caso:
Boletim do Museu Paraense Emílio Goeldi, $8,535-550$.

Alley, R.B., 2000, The Younger Dryas cold interval as viewed from central Greenland: Quaternary Science Reviews, 19, 213-226.

Alley, R.B., Ágústsdóttir, A.M., 2005, The 8k event: cause and consequences of a major Holocene abrupt climate change: Quaternary Science Reviews, 24, 1123-1149.

Aveleyra, L., 1967, Los cazadores primitivos de Mesoamérica: México, Instituto de Investigaciones Históricas, Universidad Nacional Autónoma de México, 81 p.

Balakrishnan, M., Yapp, C.J., Meltzer, D.J., Theler, J.L., 2005, Paleoenvironment of the Folsom archaeological site, New Mexico, USA, approximately $10500{ }^{14} \mathrm{C}$ yr B.P. as inferred from the stable isotope composition of fossil land snail shells: Quaternary Research, 63, 31-44.

Brenner, M., Rosenmeier, M., Hodell, D., Curtis, J., 2002, Paleoclima de la región maya: síntesis del conocimiento basado en registros paleolimnológicos, in Islebe, G. (ed.), Los Investigadores de la Cultura Maya, Tomo 1: Campeche, Universidad Autónoma de Campeche, 248-261.

Bronk-Ramsey, C., 2008, Radiocarbon dating: revolutions in understanding: Archaeometry, 50, 249-275.

Bronk-Ramsey, G., 2009, Bayesian analysis of radiocarbon dates: Radiocarbon, 51(4), 337-360.

Cook, B.R., Richards, L., Rutherford, B., 2015, Geographies of the Anthropocene: Geographical Research, 53, 231-243.

Corrales, I., 1977, Estratigrafia: Madrid, Rueda, $718 \mathrm{p}$.

Correa-Metrio, A., Bush, M.B., Cabrera, K.R., Sully, S., Brenner, M., Hodell, D.A., Escobar, J., Guilderson, T., 2012, Rapid climate change and no-analog vegetation in lowland Central America during the last 86000 years: Quaternary Science Reviews, 38 (Supplement C), 63-75. 
Crutzen, P., Stoermer, E., 2000, The "Anthropocene": Global Change Newsletter, 41, 17-18.

Cruz, J.A., Arroyo-Cabrales, J., Reynoso, V.H., 2016, Reconstructing the paleoenvironment of Loltún Cave, Yucatán, Mexico, with Pleistocene amphibians and reptiles and their paleobiogeographic implications: Revista Mexicana de Ciencias Geológicas, 33, 342-354.

Dillehay, T., 2000, The Settlement of the Americas: A New Prehistory: New York, Basic Books, $359 \mathrm{p}$

Eidt, R., 1973, A rapid chemical field test for archeological site surveying: American Antiquity, 38, 206-210.

Emery, K.F., 1986, Variation in a Tropical Gastropod Population: Implications for ancient Maya lowland subsistence patterns: Canada, Trent University, Bachelor of Science thesis, Departments of Anthropology and Biology, 134 p.

Escobar, J., Hodell, D.A., Brenner, M., Curtis, J.H., Gilli, A., Müller, A.D., Anselmetti, F.S., Ariztegui, D., Grzesik, D.A., Pérez, L., Schwalb, A., Guilderson, T.J., 2012, A 43$\mathrm{ka}$ record of paleoenvironmental change in the Central American lowlands inferred from lacustrine ostracods: Quaternary Science Reviews, 37, 92-104.

Eudave, I., 2008, Subsistencia de los cazadores recolectores, un estudio de los restos faunísticos de la cueva de Santa Marta, Chiapas: México, Escuela Nacional de Antropología e Historia, bachelor thesis in Archeology, 178 p.

Farrand, W.R., 2001, Sediments and stratigraphy in rockshelters and caves: A personal perspective on principles and pragmatics: Geoarchaeology, 16(5), 537-557.

García-Bárcena, J., Santamaría, D., 1982, La Cueva de Santa Marta Ocozocoautla, Chiapas. Estratigrafía, cronología y cerámica:
México, Instituto Nacional de Antropología e Historia, scientific collection, no. 111, 178 p. González, V.M., 2015, Relación de la herpetofauna fósil con el paleoambiente y los cazadoresrecolectores del Cuaternario tardío en la cueva de Santa Marta, Chiapas: México, Universidad Nacional Autónoma de México, bachelor thesis in Archeology, 147 p.

González, S., Jiménez, J.C., Hedges, R., Huddart, D., Ohman,J.C., Turner, A., Pompa y Padilla, J.A., 2006, Earliest humans in the Americas: new evidence from México: Journal of Human Evolution, 44, 379-387.

Gruhn, R., Bryan, A., 1977, Los Tapiales: A Paleo-indian Campsite in the Guatemala Highlands: Proceedings of the American Philosophical Society, 121, 235-273.

Haug, G.H., Hughen, K.A., Sigman, D.M., Peterson, L.C., Rohl, U., 2001, Southward Migration of the Intertropical Convergence Zone through the Holocene: Science, 293, 1304-1308.

Hodell, D.A., Turchyn, A.J., Wiseman, G.V., Escobar, J., Curtis, J.H., Brenner, M., Gilli, A., Anselmetti, F., Ariztegui, D., Perez, L., Schwalb, A., Brown, E., 2012, Late glacial temperature and precipitation changes in the lowland Neotropics by tandem measurements of $\delta^{18} \mathrm{O}$ in biogenic carbonate and gypsum hydration water: Geochimica et Cosmochimica Acta, 77, 352-368.

Jones, M.D., Leng, M.J., Eastwood, W.J., Keen, D.H., Turney, C.S.M., 2002, Interpreting stable-isotope records from freshwater snailshell carbonate: a Holocene case study from Lake Golhisar, Turkey: The Holocene, 12(5), 629-634.

Kennett, D.J., 2012, Archaic-period foragers and farmers in Mesoamerica in Nichols, D.L., Pool, C.A., (eds.), Oxford Handbook of Mesoamerican Archaeology: New York, Oxford University Press, 141-150. 
Lachniet, M.S., Asmerom, Y., Burns, S.J., Patterson, W.P., Polyak, V.J., Seltzer, G.O., 2004, Tropical response to the 8200 yr B.P. cold event? Speleothem isotopes indicate a weakened early Holocene monsoon in Costa Rica: Geology, 32(11), 957-960.

Lam, O., López-Miceli, M.A., Díaz-Cruz, J.A., Chanona-Pérez, A.K., Ramos-López, M.A., Penagos-García, F.E., 2012, Distribución y abundancia del "Shuti" Pachychilus largillierti (Pachychilidae) en la Reserva Meyapac, Municipio de Ocozocoautla, Chiapas, México: Lacandonia, 6(1), 43-54.

Leng, M.J., Lewis, J.P., 2016, Oxygen isotopes in molluscan shell: Applications in environmental archaeology: Environmental Archaeology, 21(3), 295-306.

Leyden, B.W., Brenner, M., Hodell, D.A., Curtis, J.H., 1993, Late Pleistocene climate in the Central American lowlands: American Geophysical Union Geophysical Monograph, 78, 165-178.

MacNeish, R.S., Peterson, F., 1962, The Santa Marta rock shelter, Ocozocoautla, Chiapas, México: Papers of the New World Archaeological Foundation 14: Provo, Utah, USA, Brigham Young University, Provo, Utah, $46 \mathrm{p}$.

Martin, P.S., 1967, Prehistoric overkill in Martin, P.S., Wright, H.E., Jr., (eds.), Pleistocene Extinctions. The Search for a Cause: New Haven, USA, Yale University Press, 75-120.

Martínez,J.B., 2013, Efecto reservorio en caracoles del género Pachychilus provenientes del abrigo Santa Marta, Chiapas: Veracruz, México, Universidad Veracruzana, bachelor thesis in Archeology, 173 p.

McClung, E., Acosta, G., 2015, Una ocupación del periodo de agricultura temprana en Xochimilco (ca. 4200-4000 A.N.E.): Anales de Antropología 49(2), 299-315.

Metcalfe, S.E., O'Hara, S.L., Caballero, M., Davies, S.J., 2000, Records of late PleistoceneHolocene climatic change in Mexico-A review: Quaternary Science Reviews, 19, 699-721.

Miranda, F., 1952, La vegetación de Chiapas: Tuxtla Gutiérrez, México: Ediciones del Gobierno del Estado de Chiapas, 265 p.

Neff, H., Pearsall, B., Jones, J., Arroyo, B., Freidel, D., 2006, Climate change and population history in the Pacific lowlands of southern Mesoamerica: Quaternary Research, 65, 390-400.

Niederberger, C., 1979, Early Sedentary Economy in the Basin of Mexico: Science, 203, 131-142.

Nilsson, S., Praglowski, J., 1992, Erdtman's Handbook of Palinology, Munskgaard: Copenhagen, Munksgaard International Publishers, $486 \mathrm{p}$.

Oldfield, F., Barnosky, A.D., Dearing, J., FischerKowalski, M., McNeill, J., Steffen, W., Zalasiewicz, J., 2014, The Anthropocene Review: Its significance, implications and the rationale for a new transdisciplinary journal: The Anthropocene Review, 1(1), 3-7.

Pearson, G., Cooke, R., 2002, The role of the Panamanian Land-Bridge during the initial colonization of the Americas: Antiquity, 76, 931-932.

Pérez-Crespo, V.A., Ulloa-Montemayor, X., Acosta-Ochoa, G., Arroyo-Cabrales, J., Alva-Valdivia, L.M., Morales-Puente, P., Cienfuegos-Alvarado, E., 2012, Aplicaciones de los marcadores biogeoquímicos $\delta^{13} \mathrm{C}$ y $\delta^{18} \mathrm{O}$ en Mazama americana: Revista Mexicana de Biodiversidad, 83, 587-589.

Piperno, D., 2012, The origins of plant cultivation and domestication: Current Anthropology, $52,453-470$.

Piperno, D., Bush, M., Colinvaux, P., 1991, Paleoecological perspectives on human adaptation in Panama. I. The Pleistocene: Geoarchaeology, 6, 201-226.

Piperno, D., Pearsall, D., 1998, The Origins of Agriculture in the Lowland Neotropics: San Diego, CA, Academic Press, 400 p. 
Pope, K., Pohl, M., Jones J., Lentz, D., Von-Nagy, C., Vega, F., Quitmyer, I., 2001, Origin and environmental setting of ancient agriculture in the lowlands of Mesoamerica: Science, 292, 1370-1373.

Reimer, PJ., Bard, E., Bayliss, A., Beck, J.W., Blackwell, P.G., Bronk-Ramsey, C., Buck, C.E., Cheng, H., Edwards, R.L., Friedrich, M., Grootes, P.M., Guilderson, T.P., Haflidason, H., Hajdas, I., Hatté, C., Heaton, T.J., Hoffmann, D.L., Hogg, A.G., Hughen, K.A., Kaiser, K.F., Kromer, B., Manning, S.W., Niu, M., Reimer, R.W., Richards, D.A., Scott, E.M., Southon, J.R., Staff, R.A., Turney, C.S.M., van der Plicht, J., 2013, IntCal13 and Marine13 radiocarbon age calibration curves $0-50,000$ years cal BP: Radiocarbon, 55(4), 1869-1887.

Rivera, I., 2013, Modo de vida en el bosque tropical del sureste mexicano: un acercamiento al uso de vegetación por sociedades cazadorasrecolectoras: México, Universidad Nacional Autónoma de México, master's thesis, 125 p. Ruddiman, W.F., Ellis, E.G., Kaplan, J.O., Fuller, D.Q., 2015, Defining the epoch we live in: Is a formally designated "Anthropocene" a good idea?: Science, 348(6230), 38-39.

Sánchez, S., 2005, Análisis físico-químicos de suelos y sedimentos: México, Escuela Nacional de Antropología e Historia, Instituto Nacional de Antropología e Historia, Secretaria de Educación Pública, 92 p.

Sasowsky, I.D., Mylroie, J., 2012, Studies of Cave Sediments: Physical and Chemical Records of Paleoclimate: New York, Springer, 329 p.
Stein, J., 1990, Archaeological stratigraphy in Lasca, N.P., Donahue, J., (eds.), Archaeological geology of North America: Boulder, Colorado, Geological Society of America, Centennial Special Volume 4, 513-523.

United States Department of Agriculture, Natural Resources Conservation Service (USDA), 2009, Soil survey laboratory methods manual. Version No. 4.0. Soil Survey Investigations Report No. 42, available at <https://www.nrcs.usda.gov/Internet/ FSE_DOGUMENTS/16/nrcs143_019356. pdf>, retrieved October 2016.

Vázquez-Selem, L., Heine, K., 2004. Late Quaternary glaciation of Mexico, in Ehlers, J., Gibbard, P.L. (eds.), Quaternary Glaciations - Extent and Chronology, Part III: South America, Asia, Africa, Australia, Antarctica. Elsevier, Amsterdam, 233-242.

Villegas, M., Aguilera, N., Flores, L., 1979, Método simplificado de análisis para la clasificación granulométrica de los minerales del suelo: Revista del Instituto de Geología, 12, 188-193.

Walkley, A., Black, I., 1934, An examination of the Degtjareff method for determining soil organic matter and a proposed modification of chromic acid tritation method: Soil Science, 37, 29-38. 